\title{
LEAF CHARACTERISTICS OF WILD ALMOND GENOTYPES COLLECTED FROM KAYSERI PROVINCE OF CENTRAL ANATOLIA
}

\author{
Ihsan Oguz Sanal ${ }^{1}$, Aydin Uzun ${ }^{2, *}$, Hasan Pinar ${ }^{2}$ \\ ${ }^{1}$ Provincial Directorate of Ministry of Agriculture and Forestry, Kayseri, Turkey \\ ${ }^{2}$ Erciyes University Department of Horticulture, Kayseri, Turkey
}

\begin{abstract}
Breeding studies for specific purposes cause a narrowing of the genetic pool in fruit species. For this reason, we need wild species in terms of gene source. Wild species that have adapted to different environmental conditions such as precipitation, temperature, drought, disease, pest and salinity have great importance at this point. Turkey is the center of origin for many fruits including almond species. In this study, leaf length, leaf width, leaf pedicel length and leaf color characters were examined in 39 naturally grown wild almond genotypes collected from different regions of Kayseri province in Central Anatolia. Measurements regarding to leaf characteristics were made with digital caliper. The mean values of leaf length in the study ranged from 0.65 (Genotype-48) cm to 2.48 (Genotype-18) cm. Average leaf width values varied between 0.21 (Genotype-53) cm and 1.14 (Genotype-2) cm. Leaf pedicel length values ranged from 0.13 (Genotype-26) $\mathrm{cm}$ to 0.81 (Genotype-3) cm. In the study, leaf color of 39 almond genotypes was found as follows; 19 genotypes were light green, 18 genotypes were gray, and 2 genotypes were dark green. In terms of leaf characteristics examined in the study, a significant variation was found between almond genotypes. The reason for this variety may be due to the reproduction of wild almonds in nature with seeds. This rich variation is valuable for expanding of the genetic pool in the almond species. On the other hand, these almond populations can be used for biotic and abiotic stress factors tolerant cultivar and rootstock breeding studies.
\end{abstract}

Keywords: characterization, leaf features, wild almond.

\section{INTRODUCTION}

Almonds are botanically in the stone fruits group and in taxonomy it is included in the Prunus amygdalus subgenus of the Prunus genus of the Rosaceae family of the order Rosales. It is reported that there are around 40 almond species within the P. amygdalus subgenus (Kester and Gradziel, 1996). Some botanists distinguished almond species from other Prunus species and evaluated them within the Amygdalus genus (or subgenus) (Kester et al., 1991; Bayazit, 2007). P. amygdalus Batsch. (synonym. P. dulcis Miller) has gained importance mostly for its fruit and has naturally spread in the mountainous regions of Central Asia (Iran, India and Pakistan). It has spread from ancient times until today, and from here it has spread to the Mediterranean region (Karadeniz ve Erman, 1996; Kester and Gradziel, 1998).

Turkey in case of a gene central fruit and vegetable species growing in the world, or is located within the boundaries of gene centers. The cases, be suitable ecological conditions, the presence of Turkey's migration route and on since the dawn of civilization, the history of Anatolia where many have experienced can be explained by the fact that somewhere. (Demir, 1990; Ağaoğlu et al, 1995). Turkey has a wealth of plant genetic resources, it is also the homeland of many plant species as well as almonds. 
There are many types of wild almonds spread across different parts of the world. Of these, Amygdalus orientalis Mill. (Amygdalus argentae Lam.); spreads from Iraq, Syria and West Iran fto the region up to Turkey's internal (Kester and Asay, 1975). Known as the Middle East species, $A$. orientalis has also found distribution in Central Anatolia and Southern Anatolia. This species forms plants in the form of bushes that can grow 1-2 (3) m. Leaves are dense, fruit small, hard shell and there are grooves on their shell surfaces (Denisov, 1988; Browicz and Zielinski, 1984; Browicz and Zohary, 1996; Bayazit, 2007).

The genetic resources of plants have many uses. The most important of these is the use of primitive forms and wild species, either directly or by being collected from nature. However, this method of use is limited and uneconomical in terms of the variety and variety of cultivated plants in today's conditions. Another area of use of wild populations is to expand the non-rich gene pools of modern culture varieties (Sehirali et al., 2005). Factors such as drought, changing climatic conditions and diseases-pests necessitate the breeding and use of resistant almond varieties. It is important to use wild almond species that have been adapted to abiotic stress conditions for thousands of years in the breeding of almond varieties with these characteristics. For these reasons, wild almond species are used in different parts of the world in areas such as expanding the genetic pool in almond type, resistance to diseases and other stress factors, and rootstock breeding (Bayazit, 2007).

Located in Central Anatolia, Kayseri is one of the provinces with a high population of wild almonds (Figure 1). In this study carried out in the regions where wild almond populations are located in Kayseri province, it is aimed to investigate the morphological and molecular characterization of wild almonds. The findings of the study will form the basis for the conservation and use of wild almond genetic resources in the region.

\section{MATERIALS AND METHODS}

The material of this study was composed of wild almond genotypes in Felahiye, Kocasinan, Melikgazi and Incesu districts where wild almond populations are concentrated of Kayseri Province in Central Anatolia. Leaf samples taken from 39 naturally grown wild almond genotypes and were used for the necessary measurements. Leaf length, leaf width, leaf pedicel length and leaf color characters were examined. Measurements were carried out in 3 replicates and 20 leaves per repeat, and 60 mature leaves were taken randomly from each genotype and their averages were taken (Bayazit, 2007).

\section{RESULTS AND DISCUSSION}

High level of variation was found in terms of leaf characteristics among the almond genotypes used in the study. Leaf length, leaf width, leaf pedicel length and leaf color values of genotypes provided in Table 1. Average values of leaf length varied between 0.65 (Genotype-48) $\mathrm{cm}$ and 2.48 (Genotype-18) cm. Aktepe (2013) reports that the leaf lengths of the selected species belonging to Amygdalus orientalis species, which grows naturally in Hurman Stream valley of Afsin district of Kahramanmaras province, vary between 1.16-2.16 cm. Bayazit (2007) stated in his study on selected wild almond types in Nevsehir Goreme that leaf length values varied between 1.57-3.36 $\mathrm{cm}$. On the other hand, Baninasab and Rahemi (2006), found leaf length of three wild almond ( $P$. orientalis, $P$. scoparia and, $P$. webbii) as $27.63,32.83$ and $34.10 \mathrm{~mm}$ respectively. It is seen that the most of leaf length values we obtained in the study are nearly similar to the results of other researchers. 


\begin{tabular}{lr}
\hline & $\begin{array}{c}\text { Current Trends in Natural Sciences } \\
\text { Vol. 9, Issue 18, pp. 128-132, 2020 }\end{array}$ \\
& $\begin{array}{c}\text { Current Trends in Natural Sciences (CD-Rom) } \\
\text { https://doi.org/10.47068/ctns.2020.v9i18.017 } 2284-9521\end{array}$ \\
\cline { 2 - 2 } $\begin{array}{l}\text { Current Trends in Natural Sciences (on-line) } \\
\text { ISSN: 2284-953X }\end{array}$ & ISSN-L: 2284-9521 \\
ISSN-L: 2284-9521 & \\
\hline
\end{tabular}

In the study, the average leaf width values varied between 0.21 (Type-53) $\mathrm{cm}$ and 1.14 (Type-2) $\mathrm{cm}$.

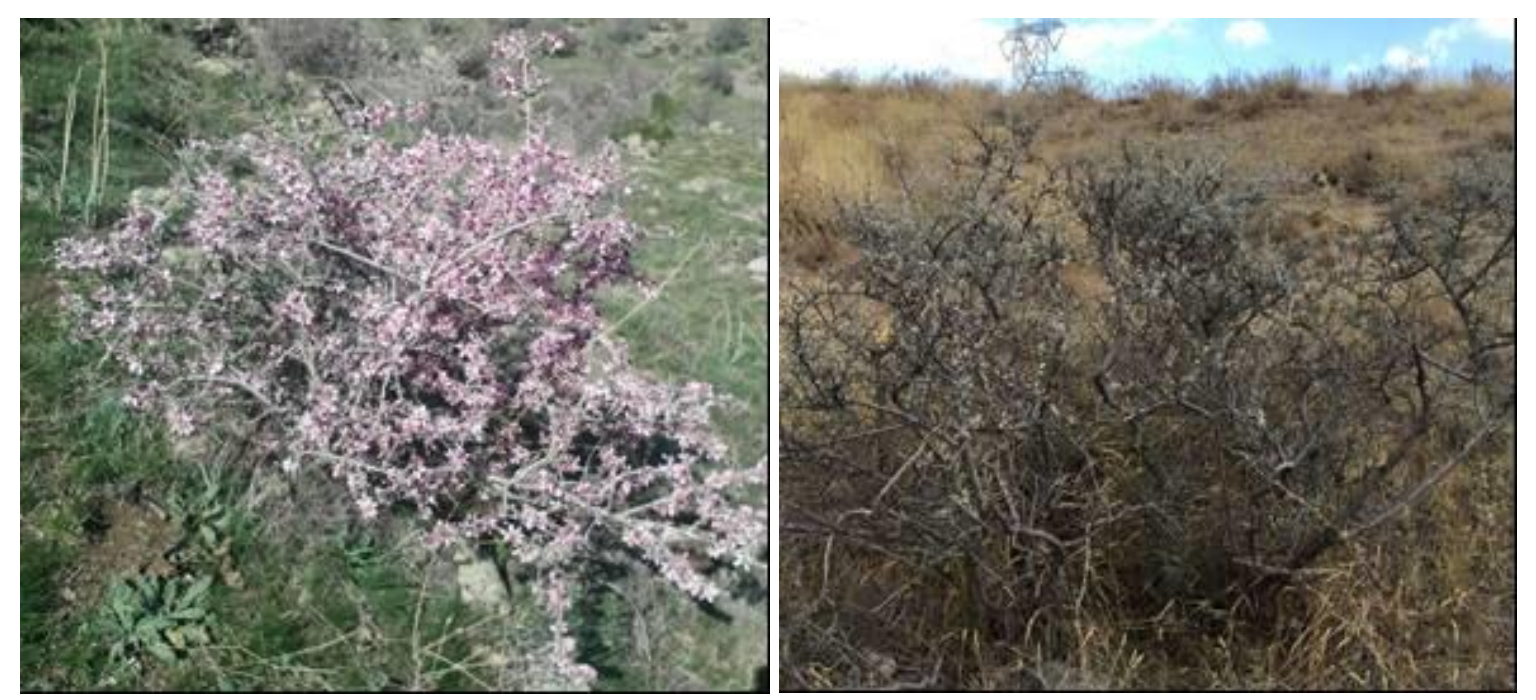

Figure 1. Some plant images of wild almond genotypes located in Kayseri province

Bayazit (2007), in his study on selected wild almond types in Nevsehir Göreme, reported that the leaf width values varied between $0.51-1.47 \mathrm{~cm}$ and the average leaf width of the selected types was $0.89 \mathrm{~cm}$. Aktepe (2013) determined that the leaf width values of genotypes belonging to Amygdalus orientalis species located in Afsin district of Kahramanmaras province ranged between 3.5-8.1 mm. It is seen that some of the leaf width values we obtained in our study are different from the results of other researchers. It is thought that this situation is caused by the genetic structure of the material studied and the differences in ecologies.

Leaf stem length values were determined between 0.13 (Type-26) $\mathrm{cm}$ and 0.81 (Type-3) $\mathrm{cm} \mathrm{3.1).}$ Baninasab and Rahemi (2006), in their study in Iran, found the petiole length values of three different wild almond species between 1.30-2.75 mm. Bayazit (2007), in his study on almond types, determined the petiole length values as $0.51-0.57 \mathrm{~cm}$ according to years. Aktepe (2013) determined the petiole length values of types belonging to Amygdalus orientalis species between 1.4-8.2 mm. The petiole length values obtained in our study are compatible with the results of other researchers. In the leaf color analysis of 39 almond types discussed in the study; It was determined that 19 types are light green, 18 types are gray and 2 types are dark green. Bayazit (2007) stated in his study that only one type of leaves selected from the Ayranc1 region were green in color, while the leaves belonging to other types were gray-green in color. Aktepe (2013), in his study on Amygdalus orientalis, reports that 11 almond types have light green leaves in 4 types and green color. It is seen that the leaf color of the types we deal with in our study shows more variation than other studies. It is considered that this situation arises from the difference between the ecology and material studied. 


\section{Current Trends in Natural Sciences}

Vol. 9, Issue 18, pp. 128-132, 2020

https://doi.org/10.47068/ctns.2020.v9i18.017

Current Trends in Natural Sciences (on-line)

Table 1. Leaf length, leaf width, leaf pedicel length and leaf color of genotypes studied

\begin{tabular}{|c|c|c|c|c|}
\hline Genotypes & Leaf length $(\mathrm{cm})$ & Leaf width (cm) & Leaf Pedicel Lenght $(\mathrm{cm})$ & Leaf Color \\
\hline Genotype 1 & $1.12 \pm 0.08$ & $0.31 \pm 0.06$ & $0.39 \pm 0.07$ & Grey \\
\hline Genotype 2 & $0.94 \pm 0.07$ & $1.14 \pm 0.05$ & $0.55 \pm 0.07$ & Grey \\
\hline Genotype 3 & $1.34 \pm 0.07$ & $0.53 \pm 0.08$ & $0.81 \pm 0.06$ & Light Green \\
\hline Genotype 4 & $0.88 \pm 0.07$ & $0.22 \pm 0.04$ & $0.35 \pm 0.08$ & Light Green \\
\hline Genotype 5 & $0.87 \pm 0.07$ & $0.22 \pm 0.04$ & $0.35 \pm 0.07$ & Grey \\
\hline Genotype 6 & $1.38 \pm 0.09$ & $0.56 \pm 0.11$ & $0.38 \pm 0.07$ & Grey \\
\hline Genotype 7 & $1.17 \pm 0.11$ & $0.19 \pm 0.06$ & $0.55 \pm 0.07$ & Grey \\
\hline Genotype 8 & $1.32 \pm 0.07$ & $0.19 \pm 0.06$ & $0.52 \pm 0.05$ & Grey \\
\hline Genotype 9 & $1.08 \pm 0.05$ & $0.52 \pm 0.10$ & $0.71 \pm 0.05$ & Light Green \\
\hline Genotype 11 & $1.3 .0 \pm 0.10$ & $0.23 \pm 0.04$ & $0.52 \pm 0.06$ & Grey \\
\hline Genotype 12 & $1.38 \pm 0.10$ & $0.25 \pm 0.04$ & $0.48 \pm 0.06$ & Light Green \\
\hline Genotype 14 & $1.43 \pm 0.07$ & $0.38 \pm 0.07$ & $0.33 \pm 0.05$ & Light Green \\
\hline Genotype 15 & $1.52 \pm 0.07$ & $0.48 \pm 0.10$ & $0.32 \pm 0.05$ & Grey \\
\hline Genotype 17 & $1.58 \pm 0.08$ & $0.40 \pm 0.09$ & $0.48 \pm 0.05$ & Light Green \\
\hline Genotype 18 & $2.48 \pm 0.07$ & $0.62 \pm 0.07$ & $0.52 \pm 0.06$ & Grey \\
\hline Genotype 20 & $1.78 \pm 0.08$ & $0.82 \pm 0.06$ & $0.32 \pm 0.05$ & DarkGreen \\
\hline Genotype 21 & $2.23 \pm 0.06$ & $0.78 \pm 0.06$ & $0.41 \pm 0.07$ & Light Green \\
\hline Genotype 23 & $1.14 \pm 0.09$ & $0.50 \pm 0.10$ & $0.24 \pm 0.04$ & Light Green \\
\hline Genotype 25 & $1.20 \pm 0.11$ & $0.61 \pm 0.10$ & $0.41 \pm 0.07$ & Grey \\
\hline Genotype 26 & $1.00 \pm 0.07$ & $0.37 \pm 0.07$ & $0.13 \pm 0.02$ & Light Green \\
\hline Genotype 28 & $1.00 \pm 0.07$ & $0.21 \pm 0.04$ & $0.40 \pm 0.08$ & Light Green \\
\hline Genotype 29 & $1.68 \pm 0.07$ & $0.86 \pm 0.09$ & $0.45 \pm 0.07$ & Light Green \\
\hline Genotype 30 & $1.08 \pm 0.06$ & $0.44 \pm 0.10$ & $0.31 \pm 0.05$ & Light Green \\
\hline Genotype 31 & $1.80 \pm 0.08$ & $0.75 \pm 0.09$ & $0.45 \pm 0.07$ & Grey \\
\hline Genotype 35 & $1.20 \pm 0.10$ & $0.60 \pm 0.07$ & $0.30 \pm 0.05$ & Grey \\
\hline Genotype 36 & $1.50 \pm 0.07$ & $0.80 \pm 0.07$ & $0.51 \pm 0.08$ & Grey \\
\hline Genotype 37 & $1.25 \pm 0.11$ & $0.63 \pm 0.07$ & $0.34 \pm 0.05$ & Light Green \\
\hline Genotype 40 & $2.32 \pm 0.06$ & $0.92 \pm 0.08$ & $0.44 \pm 0.07$ & Light Green \\
\hline Genotype 41 & $0.88 \pm 0.08$ & $0.38 \pm 0.06$ & $0.21 \pm 0.04$ & Grey \\
\hline Genotype 42 & $0.76 \pm 0.07$ & $0.39 \pm 0.06$ & $0.21 \pm 0.04$ & Grey \\
\hline Genotype 43 & $1.02 \pm 0.06$ & $0.47 \pm 0.06$ & $0.33 \pm 0.06$ & Dark Green \\
\hline Genotype 46 & $0.99 \pm 0.06$ & $0.43 \pm 0.05$ & $0.21 \pm 0.04$ & Light Green \\
\hline Genotype 47 & $1.13 \pm 0.08$ & $0.51 \pm 0.06$ & $0.32 \pm 0.06$ & Grey \\
\hline Genotype 48 & $0.65 \pm 0.07$ & $0.42 \pm 0.07$ & $0.23 \pm 0.05$ & Light Green \\
\hline Genotype 49 & $1.28 \pm 0.10$ & $0.39 \pm 0.07$ & $0.45 \pm 0.06$ & Grey \\
\hline Genotype 53 & $1.12 \pm 0.08$ & $0.21 \pm 0.02$ & $0.33 \pm 0.05$ & Grey \\
\hline Genotype 54 & $1.15 \pm 0.09$ & $0.31 \pm 0.06$ & $0.40 \pm 0.07$ & Light Green \\
\hline Genotype 55 & $1.05 \pm 0.07$ & $0.22 \pm 0.03$ & $0.32 \pm 0.06$ & Light Green \\
\hline Genotype 56 & $1.38 \pm 0.11$ & $0.32 \pm 0.07$ & $0.58 \pm 0.05$ & Light Green \\
\hline
\end{tabular}




\section{CONCLUSIONS}

Our results obtained from this study revealed that wild almond genotypes grows naturally in Kayseri province contain significant leaf diversity. It is predicted that there is variation among these wild almond genotypes in terms of tolerance to biotic and abiotic stress factors. It is important to use this variety for protection, drought, biotic stress and rootstock development studies. IOt is reported that, use of wild species in breeding programs is very suitable for increasing the genetic diversity of cultivated cultivars and expanding the gene pool (Wolko et al., 2010; Wohrmann et al., 2011).

\section{REFERENCES}

Agaoglu, Y.S., Çelik, H., Çelik, M., Fidan, Y., Gülşen, Y., Günay, A., Halloran, N., Köksal, İ. Ve Yanmaz, R. (1995). Genel Bahçe Bitkileri. [General Fruit Growing]. A.U.Z.F. No:4, 339 p. (in Turkish).

Baninasab, B., Rahemi, M. (2006). Evaluation of Three Wild Species of Almond on The Basis of Their Morphological Characters. J. Cent. Eur. Agric. 7: 4, 619-626.

Bayazit, S. (2007). Türkiye'nin Farklı Ekolojilerindeki Yabani Badem Genotiplerinde Fenolojik, Morfolojik ve Pomolojik Özellikler ile Moleküler Yapıların Tanımlanması. [Phenological, Morphological, Pomological and Molecular Characteristics of The Wild Almond Genotypes Collected From Different Ecotypes of Turkey] Phd. Thesis. Cukurova Universitesi Fen Bilimleri Enst. Adana. (in Turkish).

Browicz, K. and Zielinski, J. (1984). Chology Of Trees and Shrubs in SouthWest Asia and Adjacent Regions. Polish Scientific Publishers, Vol. 8. Warzsawa-Poznan 80 p.

Browicz, K. and Zohary, D. (1996). The Genus Amygdalus L.(Rosaceae) Species Relationships, Distribution and Evolution Under Domestication. Genetic Res. and Crop Ev, 43, 229-247.

Demir, I. 1990. Genel Bitki Islahı [General Plant Breeding]. E. Ü. Ziraat Fakültesi Yayınları No 496: 366 S. E.Ü.Z. F. Ofset Atölyesi Izmir. (in Turkish)

Denisov, V.P., 1988. Almond Genetic Resources in the USSR and Their Use in Production and Breeding. Acta. Hort. 244, 299-306.

Karadeniz, T. Ve Erman, P. (1996). Sirr'te Yetiştirilen Bademlerin (Prunus communis L.) Seleksiyonu [Selection of Almonds Growing in Siirt Province] I. Findık ve Diğer Sert Kabuklu Meyveler Sempozyumu, 10-11 Ocak, O.M.U. Ziraat Fakültesi, Samsun, S: 324-343. (in Turkish).

Kester D. E., Gradziel T.M. (1998). The University Of California Almond Breeding Programme:I. Historical Aspects. Nucis 7, 8-10.

Kester, D. E., Asay, R. (1975). Almonds. Advances in Fruit Breeding. (Ed. J Janick, J.N. Moore). Purdue Univ. Pres; Westlafeyette, İndiana, p.387-418.

Kester, D. E., Gradziel, T.M. Grassely, C. (1991). Almonds (Prunus). Genetic Resources of Temperate Fruits and Nut Crops. Int. Soc. Hort. Sci. 701-758.

Kester, D.E. Gradziel, T.M. (1996). Almonds. P.1-97. In: J.N. Moore, and J. Janick (Eds.) Fruit Breeding. John Wiley \& Sons, New York, USA.

Sehirali, S., Özgen, M., Karagöz, A., Sürek, M., Adak, A., Güvenç, İ., Tan, A., Burak, M. Ve Kaymak, Ç. (2005). Bitki Genetik Kaynaklarının Korunma ve Kullanımı. [Protection and Utilization of Plant Genetic Resources]. Türkiye Ziraat Mühendisliği VI. Teknik Kongresi. (in Turkish).

Wohrmann, T., Guicking, D., Khoshbakht, K., Weising, K. (2011). Genetic variability in wild populations of Prunus divaricata Ledeb. in northern Iran evaluated by EST-SSR and genomic SSR marker analysis. Genetic Resources and Crop Evolution, 58, 1157-1167.

Wolko, L., Antkowiak, W., Sips, M., Slomski, R. (2010) Self incompatibility alleles in Polish wild pear (Pyrus pyraster (L.) Burgsd.): a preliminary analysis. Journal of Applied Genetics, 51, 33-35. 